\title{
MENINGKATKAN HASIL BELAJAR KOGNITIF MAHASISWA DENGAN MENGGUNAKAN MODEL PEMBELAJARAN KOOPERATIF GROUP INVESTIGATION (GI)
}

\author{
Tri Maniarta Sari ${ }^{1 *}$, Ernawati $^{1}$ \\ ${ }^{1}$ Prodi Pendidikan Biologi, Fakultas Keguruan dan Ilmu Pendidikan, Universitas Sembilan Belas November Kolaka \\ email: trimaniarta@gmail.com
}

\begin{abstract}
Abstrak
Penelitian ini bertujuan untuk melihat peningkatan hasil belajar kognitif mahasiswa yang dibelajarkan dengan model pembelajaran kooperatif Group Investigation (GI). Penelitian ini dilakukan di Universitas Negeri Malang. Subjek dari penelitian ini yaitu mahasiswa angkatan 2016 kelas A yang menempuh matakuliah keanekaragaman hewan dengan jumlah mahasiswa sebanyak 32 orang. Penelitian ini merupakan penelitian dengan pendekatan kualitatif. Jenis penelitian ini adalah penelitian tindakan kelas (PTK) berbasis Lesson Study (LS) yang dilakukan dalam 2 siklus selama 1 semester. Data hasil belajar kognitif diperoleh dari hasil tes essay yang didukung hasil observasi, dan pengerjaan LKM. Hasil penelitian menunjukkan bahwa model pembelajaran GI mampu meningkatkan hasil belajar kognitif mahasiswa dengan peningkatan sebesar 12,22.
\end{abstract}

Kata kunci: Hasil Belajar Kognitif, Model Pembelajaran, dan Group Investigation (GI)

\begin{abstract}
This study aims to see an increase in the cognitive learning outcomes of students who are taught with the cooperative learning model Group Investigation (GI). This research was conducted at the State University of Malang. The subjects of this study were 2016 class A class 2016 students taking animal diversity courses with 32 students. This research is a qualitative approach research with Lesson Study (LS) based classroom action research (CAR) had two cycle in 1 semester. Data on cognitive learning outcomes were obtained from essay test results supported by observations, and work on the LKM. The results showed that the GI learning model was able to improve student cognitive learning outcomes with enhancement 12,22.
\end{abstract}

Keywords: cognitive learning outcomes, learning model and group investigation(GI) 


\section{PENDAHULUAN}

Pendidikan adalah hal yang penting untuk suatu bangsa, dengan pendidikan akan menentukkan masa depan sebuah bangsa. Untuk membentuk suatu pendidikan yang berkualitas dibutuhkan kurikulum, guru dan proses belajar mengajar yang saling berkesinambungan (Hapsari, dkk, 2019). Sehingga keberhasilan dari pendidikan itu dapat dilihat dari bagaimana pelaksanaan pembelajaran di kelas. Segala keputusan dalam memilih suatu model ataupun strategi yang dilakukan oleh guru sangat menentukkan ketercapaian dari tujuan pendidikan itu sendiri, salah satunya yaitu peningkatan hasil belajar kognitif siswa (Yaqin, dkk, 2018).

Peningkatan hasil belajar juga diharapkan terjadi pada matakuliah keanekaragaman hewan. Matakuliah keanekaragaman hewan merupakan mata kuliah wajib yang diiukuti oleh mahasiswa pendidikan biologi di semester ganjil yang diharapkan dapat dipahami dengan baik oleh mahasiswa karena hal tersebut merupakan bekal ilmu untuk mahasiswa pendidikan biologi yang diharapkan akan menjadi pendidik di masa depan. Karena dengan memahami materi dari mata kuliah ini dengan baik diharapkan ketika telah menjadi guru dapat mengajarkan materi tersebut dengan baik dan matang (Indriwati, dkk, 2018).

Namun, fakta di lapangan yang terjadi ialah hasil belajar belum sepenuhnya berkembang seperti yang terdapat pada mahasiswa yang memprogram mata kuliah keanekaragaman hewan pada offering $A$ di Universitas Negeri Malang. Hal ini didukung oleh hasil observasi yang menunjukkan bahwa mahasiswa masih cenderung memiliki hasil belajar kognitif yang cukup rendah. Hal ini diketahui pada saat dosen memberikan soal evaluasi dengan dengan tingkatan C4 hingga $\mathrm{C} 5$, sebanyak $60 \%$ dari jumlah mahasiswa tidak dapat menjawab soal tersebut dengan tepat. Ketika mahasiswa melakukan diskusi, mahasiswa masih belum dapat mengaitkan materi yang sedang dipelajari, dan ketika mereka mengungkapkan pendapat masih sebatas apa yang tertulis di buku teks bukan diuraikan dengan menggunakan kata-kata sendiri.

Hal ini diperkuat dengan penelitian yang dilakukan oleh Indriwati, dkk (2018) yang menyatakan hasil belajar mahasiswa program studi pendidikan biologi yang memprogram mata kuliah keanekaraman hewan masih rendah. Hal ini juga didukung oleh penelitian yang dilakukan oleh Yaqin, dkk (2018) yang menyatakan hasil belajar mahasiswa dan keterampilan kolaborasi siswa masih rendah.

Berdasarkan perbedaan antara fakta di lapangan dengan apa yang diharapkan maka perlu adanya upaya untuk menanggulangi permasalahan tersebut. Salah satu upaya yang dapat dilakukan yaitu dengan memilih strategi yang tepat dalam proses perkuliahan atau pembelajaran di kelas.

Model pembelajaran yang akan mendukung peserta didik dalam berdiskusi dan bekerja sama sehingga dapat membantu peserta didik untuk meningkatkan hasil belajarnya yaitu model pembelajaran kooperatif Group Investigation (GI) (Aliman, 2016). Model pembelajaran kooperatif Gl merupakan model pembelajaran kooperatif yang pelaksanaannya bersifat konstruktivisme karena dalam prosesnya, siswa membangun sendiri pengetahuannya dan guru berperan sebagai fasilitator (Slavin, 1995). Sehingga model pembelajaran kooperatif GI mampu melatih siswa untuk membangun konsep secara mandiri. Dalam model pembelajaran ini, siswa dilatih untuk membuat rancangan 
pembelajarannya sendiri mulai dari topik yang akan diselidiki berdasarkan tema yang diberikan oleh guru selaku fasilitator (Putra dkk, 2018).

Model pembelajaran $\mathrm{Gl}$ dapat memfasilitasi peserta didik untuk saling berinteraksi dan mengumpulkan banyak informasi sambil bekerjasama secara berkelompok untuk menyelidiki permasalahan, perencanaan dan melakukan presentasi, dan mengevaluasi hasil diskusi yang telah dilakukan (Tsoi, 2004). Model pembelajaran ini mengharuskan peserta didik dapat berkomunikasi dengan baik dan juga meningkatkan keterampilan proses kelompoknya (group process skills).

Model pembelajaran Gl dapat menciptakan suasana pembelajaran yang lebih efektif. Selain itu kerjasama kelompok antar peserta didik dalam proses pembelajaran akan membangkitkan semangat mereka untuk memiliki keberanian dalam berpendapat dan memberikan informasi dengan peserta didik yang lainnya dalam membahas materi yang dibelajarkan. (Sudewi, dkk, 2014).

Berdasarkan uraian latar belakang di atas, maka dianggap perlu dilakukannya penelitian dengan menerapkan model pembelajaran kooperatif Group Investigatin (GI) untuk meningkatkan hasilbelajar mahasiswa yang memprogram matakuliah keanekaragaman hewan.

\section{METODE}

Penelitian yang dilakukan ini adalah Penelitian Tindakan Kelas (PTK) berbasis Lesson Study (LS). Langkahlangkah penelitian yang dilakukan yaitu perencanaan, pelaksanaan, pengamatan, refleksi serta pelaporan. Subjek dalam penelitian ini adalah mahasiswa yang memprogram matakuliah keanekaragaman hewan offering A Universitas Negeri Malang semester ganjil tahun ajaran 2017/2018 yang berjumlah 32 orang. Objek yang diukur dalam penelitian ini adalah hasil belajar kognitif mahasiswa. Instrumen perlakuan yang digunakan yaitu berupa RPS, lembar keterlaksanaan sintaks, catatan lapangan, LKM, lembar observasi LS. Sedangkan untuk instrumen pengukuran yang digunakan yaitu soal tes hasil belajar kognitif.

Penelitian ini merupakan penelitian PTK berbasis Lesson study (LS) yang dilakukan sebanyak 2 siklus yaitu siklus pertama dan siklus kedua. Pada masing-masing siklus memiliki empat tahapan, yaitu (1) perencanaan, pelaksanaan, (3) pengamatan dan (4) refleksi. Empat tahapan tersebut merupakan suatu kegiatan yang berkesinambungan dan berurutan. Arikunto (2009) menggambarkan desain penelitian tindakan yang dapat dilihat pada Gambar 1.



Gambar 1. Desain Penelitian Tindakan

Keberhasilan dalam penelitian PTK ini dapat dilihat setelah dilakukannya tindakan yaitu perubahan proses pembelajaran dan hasil belajar ke arah yang lebih baik. Perubahan yang diharapkan pada penelitian ini ialah adanya peningkatan hasil belajar kognitif mahasiswa yang memprogram 
Keanekaragaman Hewan dengan diterapkannya model pembelajaran kooperatif tipe Group Investigation (GI). Kriteria keberhasilan tindakan ini ditandai dengan meningkatnya persentase hasil belajar kognitif mahasiswa pada matakuliah Keanekaragaman Hewan dari siklus I ke siklus II.

Sintaks dari model pembelajaran kooperatif Group Investigation (GI) menurut Slavin (2010) yaitu pada Mengidentifikasi topik dan mengatur peserta didik ke dalam kelompok, Merencanakan tugas yang akan dipelajari, Melaksanakan investigasi, Menyiapkan laporan akhir, Mempresentasikan laporan akhir, dan evaluasi.

Lesson study yang diterapkan pada penelitian ini dilakukan pada setiap siklusnya. Adapun tahapan dari lesson study yaitu Plan, do, See. Dimana tahapan Plan ini dosen merancang atau merencanakan proses pembelajaran yang akan dilaksanakan. Do merupakan tahapan pelaksanaan, dalam pelaksanaan ini dibantu oleh bebeapa rekan dosen untuk mengobservasi rangkaian pembelajaran yang dilaksanakan. Dan tahapan See adalah tahapan refleksi, dimana setiap dosen yang melaksanakan pembelajaran merefleksi proses pembelajaran yang sudah dilaksanakan dan dibantu oleh observer yang memberikan segala masukan dan penguatan atas proses pembelajaran yang telah dilakukan. Refleksi yang dilakukan pada tahap See sangat penting untuk menentukkan perubahan rencana yang akan dilakukan pada pembelajaran berikutnya. Dimana dosen diharapkan untuk memperbaiki kelemahan yang terjadi pada siklus sebelumnya dan mempertahankan bagian yang menjadi kelebihan pada pembelajaran tersebut.

\section{HASIL DAN PEMBAHASAN}

Data hasil belajar kognitif mahasiswa diperoleh dari tes hasil belajar kognitif mahasiswa. Adapun skor hasil belajar kognitif dari pelaksanaan PTK-LS siklus I sampai dengan siklus II dapat dilihat pada Gambar 2.

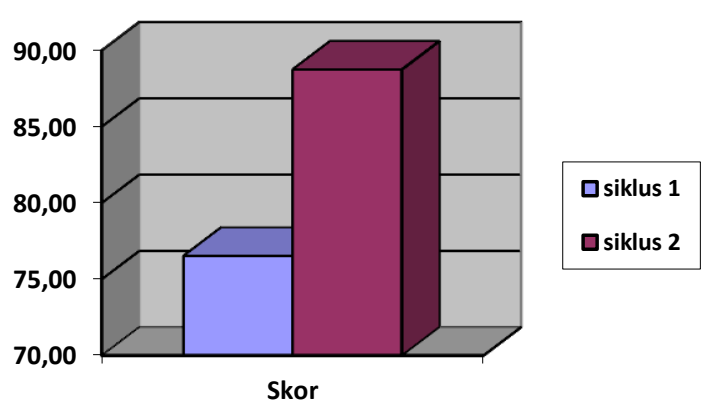

Gambar 2. Grafik Peningkatan Hasil Belajar Kognitif dari Siklus 1 ke Siklus 2

Berdasarkan Gambar 2, diketahui bahwa hasil belajar kognitif mahasiswa mengalami peningkatan dari siklus I sampai dengan siklus II dengan kategori baik ke sangat baik. Peningkatan terlihat dari siklus I, dimana nilai hasil belajar kognitif mahasiswa memiliki rata-rata 76,52, sedangkan pada siklus II terjadi peningkatan menjadi 88,74.

Peningkatan hasil belajar kognitif mahasiswa dari siklus I hingga siklus II pada pembelajaran $G$ l tidak terlepas dari karakteristik model pembelajaran GI. Setiap kegiatan yang dilakukan dalam sintaks model pembelajaran GI menunjang pembelajaran sehingga dapat meningkatkan hasil belajar kognitif mahasiswa. Belajar merupakan proses untuk mengembangkan pemikiran peserta didik untuk mengkonstruk kerangka pengertian yang bervariasi antara satu dengan yang lainnya. Selain itu belajar yang bermakna dapat diwujudkan dengan proses refleksi, pemecahan konflik, dialog, penelitian, pengujian hipotesis, pengambilan keputusan, dan lain-lain. 
Dalam setiap langkahnya pemikiran peserta didik selalu dilibatkan sehingga peningkatan pemikiran peserta didik semakin optimal. Dan semua itu dapat diperoleh dalam model pembelajaran $\mathrm{GI}$ (Sudarsana, 2018).

Salah satu kegiatan dalam sintaks model pembelajaran $\mathrm{Gl}$ ialah Kegiatan mengidentifikasi masalah, dan membentuk solusi. Pada tahapan ini siswa diharapkan untuk lebih memahami materi yang diberikan sehingga dapat mengidentifikasi masalah yang ada dan menganalisis teori yang ada sehingga dapat memberikan solusi yang efektif. Sintaks pada pembelajaran $G I$ dapat meningkatkan hasil belajar kognitif mahasiswa secara sistematis dan terencana (Polya, 1988).

Aktivitas membuat rumusan pertanyaan dan memprediksi jawaban dalam mengidentifikasi masalah juga akan melatih siswa untuk lebih memahami materi yang diberikan, karena aktivitas tersebut merupakan bagian dari memonitor pemahaman siswa. Sehingga secara tidak langsung dapat membantu siswa untuk meningkatkan kognitif siswa khususnya pada tingkatan C2 C3 dan C4. King, et al (2010) menjelaskan bahwa membuat pertanyaan dan memprediksi jawaban dapat membantu mahasiswa untuk lebih memperhatikan proses penyelesaian masalah, memonitor perkembangannya, dan mendorong keberhasilan mahasiswa dalam memecahkan masalahnya. Dalam proses membuat pertanyaan dan memprediksi tidak saja membutuhkan pemahaman dari materi namun juga analisis yang matang sehingga pertanyaan yang dibuat akan sesuai dengan prediksi yang diharapkan (Aljebari, 2015).

Pertanyaan adalah media yang dapat dipakai untuk mengembangkan kemampuan berpikir mahasiswa (Naderi, et al., 2010). Sehingga dengan membuat pertanyaan dalam bentuk rumusan masalah dan juga solusi dari permasalahan tersebut, mahasiswa diharapkan harus lebih memahami teori dan materi yang ada dan mengeksplorasi berbagai sumber teori atau materi untuk mensintesis penyelesaian masalah yang tepat dan sesuai. Eksplorasi merupakan proses yang dilalui oleh mahasiswa dalam mencari sesuatu teori atau hal lain yang berhungan dengan masalah yang ada. Informasi yang ditemukan dapat berupa informasi yang tertera eksplisit maupun insplisitdan dapat dihungkan pada masalah yang ada serta menghubungkan masalah yang ada dengan pengetahuan sebelumnya. Eksplorasi dapat menjadi salah satu mediayang membantu mahasiswa untuk memunculkan ide baru. Hal ini didukung oleh Osborn (1953) yang menyatakan bahwa dalammembuat ide yang bervariasi dalam menyelesaikan suatu permasalahandapat bermanfaat dalam memberdayakan kognitif siswa.

Sintaks berikutnya yaitu constructing solution, dimana mahasiswa mengakses segala materi atau teori yang berkaitan dengan masalah yang ditemukan untuk mensitesis atau membangun solusi dari permasalahan tersebut. Menurut Polya (1988) dalam memahami masalah mahasiswa diharapkan untuk mendapatkan berbagai informasi, gambar, atau tabel untuk memecahkan masalah dan menemukan solusi yang diharapkan.Hal ini sejalan dengan pendapat Carson (2007) yang menyebutkan mahasiswa membutuhkan informasi yang cukup untuk memulai menyelesaikan suatu masalah. Dengan demikian, pembelajaran $G$ memiliki potensi yang lebih tinggi dalam memberdayakan keterampilan berpikir kreatif serta meningkatkan hasil belajar kognitif.

Krulick dan Rudnick (1987) menyatakan dengan memberikan 
perhatian, keingintahuan, dan fokus dalam menemukan bagaimana cara menyelesaikan masalah dan menginvestigasi masalah dapat memberikan pengaruh kepada mahasiswa berupa keyakinan dalam menyelesaikan masalah yang mereka hadapi. Tahap constructing solution mahasiswa dilatih untuk menganalisis dan mensintesis informasi yang relevan dengan permasalahan yang dihadapi dari hal-hal tahapan aktivitas sebelumnya untuk menciptakan solusi yang diharapkan.

Rangkaian sintaks pada pembelajaran GI medukung serta memfasilitasi setiap mahasiswa untuk menggunakan setiap tingkatan kognitif dalam memecahkan setiap permasalahan yang dihadapi dalam materi yang di berikan. Pada setiap tahapan sintaks model pembelajaran kooperatif $\mathrm{Gl}$ ini mulai dari indetifikasi topic hingga evaluasi melatih mahasiswa untuk menggunakan kemampuan berpikir dan kognitifnya agar dapat mendapatkan hasilyang maksimal. Sehingga hal ini dapat meningkatkan hasil belajar kognitif siswa.

Penelitian tindakan kelas (PTK) berbasis lesson study ini berbeda dengan penelitian PTK pada umumnya. Dimana pada penelitian ini diselipkan kegiatan Lesson study yaitu berupa Plan, Do dan See. Tahapan-tahapan tersebut di masukkan pada setiap siklus dari PTK. Dan dengan adanya penerapan Lesson Study dalampenelian ini mendapat bantuan dari beberapa observer untuk memberikan masukkan, saran maupun solusi dari permasalahan yang terjadi dikelas dari pelaksanaan pembelajaran disetiap siklusnya, sehingga masukkan yang diberikan lebih banyak sehingga pelaksnaan pada siklus selanjutnya dapat lebih baik (indriwati, dkk,2018).

\section{PENUTUP}

\section{Simpulan}

Model pembelajaran Group Investigation (GI) meningkatkan hasil belajar kognitif mahasiswa yang ditandai dengan peningkatan rata-rata hasil belajar kognitif mahasiswa sebesar 12,22 yang didapatkan melalui hasil tes kognitif mahasiswa yang didukung pula dengan catatan lapangan, dan hasil pengerjaan LKM.

\section{Saran}

Hasil pelaksanaan PTK-LS ini dapat dijadikan alternatif untuk meningkatkan hasil belajar kognitif mahasiswa. Selain itu, dari sudut pandang kegiatan LS, kegiatan ini dapat dilakukan oleh para pendidik dan calon pendidik untuk meningkatkan kualitas pelaksanaan pembelajaran di kelas secara berkolaborasi.

\section{DAFTAR PUSTAKA}

Aljaberi, R. (2015). Creative and Its Relation to Academic Achievement and Teaching Performance of PreService Female Teachers in Ajman University in UAE. Procedia - Social and Behavioral Sciences, 174 ():560 - 567.

Aliman, Muhammad. (2016). Model Pembelajaran Group Investigation Berbasis Spasial Thinkin. Proceeding Seminar Nasional Geofrafi "Kecerdasan Spasial dalam Pembelajaran dan Perencanaan Pembangunan"

Arikunto, Suharsimi. (2009). Dasar-Dasar Evaluasi Pendidikan. Jakarta: PT. Bumi Aksara.

Borg, W.R. \& Gall, M.D. (1983). Educational Research. New York: Longman Inc. 
Carson, J. (2007). A Problem with Problem Solving:Teaching Thinking without Teaching Knowledge. (12)2: 7-14.

Hapsari, E.E., dkk. (2019). Strategi Guru Meningkatkan Hasil Belajar Menggunakan Pendekatan Saintifik di Sekolah Dasar. Jurnal Basicedu Research \& Learning in Elementary Education, 3(3):850-860.

Indriwati, S.E., dkk. 2018. Penerapan model pembelajaran inkuiri terbimbing berbasis lesson study pada matakuliah keanekaragaman hewan untuk meningkatkan kecakapan komunikasi dan hasil belajar kognitif mahasiswa pendidikan biologi. Jurnal Pendidikan Biologi vol 9(2): 38-46.

King, F.J., Goodson, L., M.S. \& Rohani, F.(2010). Higher Order Thinking Skills. Assessment \& Evaluation Educational Service Program.

Kurlick ,S. and Rudnick, J.A. (1996). The New Source Book Teaching Reasioning and Problem Solving in Junior and Senior High School. Massachussetts: Allyn \& Bacon.

Naderi, H., Abdullah, R., Aizan, H.T., Sharir, J., \& Kumar, V. (2010). Relationship between creativity and academic achievement: A study of gender differences. Journal of American Science, 6(1): 181-190.

Osborn, E. P. (1953). The Nature Of Creativity As Manifest In Its Test. New York: Cambridge University Press.

Polya, G. (1988). How to Solve It. Princeton: Princeton University Press.

Putra, P.G.N., dkk. (2018). Pengaruh Model Pembelajaran Kooperatif Tipe Group Investigation (GI) Berbasis Lesson Study Terhadap Penguasaan Konsep IPA. Jurnal
Pedagogi dan Pembelajaran vol. 1 (2).

Slavin, Robert. E. (2010). Cooperative Learning Teori, Riset dan Praktik. Bandung: Nusa Media.

Sudarsana, I Ketut. (2018). Pengaruh Model Pembelajaran Kooperatif Terhadap Peningkatan Mutu Hasil Belajar Siswa. Jurnal Penjamin Mutu Lembaga Penjamin Mutu 4(1): 21-31.

Sudewi, Ni L., dkk. (2014). Studi Komparasi Penggunaan Model Pembelajaran Problem Based Learning (PBL) dan Kooperatif Group Investigation (GI) Terhadap Hasil Belajar Berdasarkan Taksonomi Bloom. eJournal Program Pascasarjana Universitas Pendidikan Ganesha Program Studi IPA vol. 4.

Trianto.(2010). Model Pembelajaran Terpadu. Jakarta: Bumi Aksara.

Tsoi, M.F., Ngoh, K. G., \& Lion, S.C.(2004). Using Group Investigation for Chemistry in Teacher Education.Asia Fasifik Forum on Science Learning and Teaching (Online). Vol 5. Issue 1 article 6.

Wiranata, I Ketut., dkk. (2013) Pengaruh Model Pembelajaran Kooperatif Tipe Investigasi Kelompok (Group Investigation) Terhadap Keterampilan Proses dan Hasil Belajar Sains Siswa SMP. e-Journal Program Pascasarjana Universitas Pendidikan Ganesha Program Studi IPA vol. 3.

Yaqin, M.A., dkk. (2018). Think-PairSquare Learning: Improving Student's Collaborative Skills And Cognitive Learning Outcome On Animal Diversity Course. Indonesian Journal of Biology Educationvol 4(2):135-142. 